\title{
殺虫剂残渣の生物試験法に関する研究
}

\author{
第 III 報 Knock down 効力の評価に影響する環境湿度について
}

\section{Studies on biological assay of insecticide residues (III) On the relative humidity affecting knock down effect}

\author{
井上 義 郷* \\ Yoshisato Inoue
}

殺虫剂の残留処理面の knock down 効力を評価寸る 場合，全く同一の試験方法においても，しばしば $\mathrm{KT}_{50}$ 值が 5 １0倍近くも変動することがあるので，それに 関する問題点の検討を行なつてきたが，残渣の knock down 効果を大きく変動させる要因の一つは, その処理 面に存在する微量の moisture であることを実験的に確 認し，第I報では moisture の影響とそれに関連するい

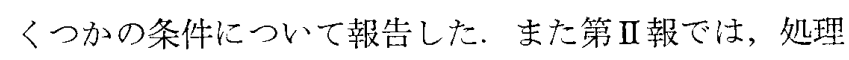
面に㧍ける残渣の行動と moisture の意義について考察 し，特に吸収性の処理面では撒布量と有効残渣量とはは つきりと区別し，この有効残渣量の変動に関与する条件 に注目すべきことを報告した。

今回沈かる处理面の残渣の行動に影響する moisture と密接な関連を持つ環境湿度をとりあげ，その影響に関 する検討を行なつたので報告する。なお，この研究の一 部は第 14 回衛生動物学会大会で講演した.

本文に入るに先だち，常々御指導を頂いている朝比奈 正二郎博士ならびに安富和男博士に謝意を表する。また 供試虫の飼育を担当されている久保田和美氏に感謝寸 る.

\section{実験材料および方法}

供試昆虫: この実験には前報と同様,イエバエ成虫を 指示昆虫として用い，その 30 頭(雙雄比 1 対 1) 宛老 1 群として取扱つた。なお，供試イエバエ Musca domestica vicina Maq. (高梘系) は当研究室の $28^{\circ} \mathrm{C}$ の恒温飼 育室で豆腐粕培基 (豆腐粕 $1 \mathrm{~kg}$ にエビオス $35 \mathrm{~g}$ 混入) を用いて飼育羽化させた，羽化後 $4 \sim 7$ 日目の成虫であ る.

供試残渣：前報の 実験結果に基いて, moisture の影 響が最も顐著な DDVP を選び，その $0.3 \%$ アトン溶

* 国立予防衛生研究所衛生昆虫部

Department of Medical Entomology, National Institute of Health, Tokyo
液を濾紙上に $50 \mathrm{cc} / \mathrm{m}^{2}$ 宛撒布し，そのまま下記条件の 恒温室内に 24 時間放置した乾燥残渣考実験に用いた。

環境湿度の条件 : Zwölfer の方法に基き, dessicator (径 $30 \mathrm{~cm}$, 高さ $20 \mathrm{~cm}$, 容量約 $14 l$ ) の中に塩類の過飽 和溶液を入れ, 次のように 3 段階の湿度環境をあらかじ め準備しておき，それらを実験们利用した。なお，表示 の関倸湿度はミニマの鋭感湿度計で測定した結果の上限 おょび下限である。 また総ての実験は $24 \sim 25^{\circ} \mathrm{C}, \mathrm{R} . \mathrm{H}$. $33 \sim 45 \%$ の恒温室内で実施した。

低湿度環境 $\rightarrow$ R.H. $27 \sim 33 \%\left(\mathrm{MgCl}_{2} \cdot 6 \mathrm{H}_{2} \mathrm{O}\right)$

中湿度環境 $\rightarrow$ R.H. $60 \sim 70 \%(\mathrm{NaCl})$

高湿度環境 $\rightarrow$ R.H. $85 \sim 94 \%\left(\mathrm{H}_{2} \mathrm{O}\right)$

実験方法：あらかじめ準備しておいた供試残渣を，ま ず， 3 段階に準借されているそれぞれの湿度環境下に移 し, 所定の封間それらの条件にさらしたのちに取出し， 直ちに湿度の影響をうけたと思われるそれぞれの残渣に 供試虫を継続的に接触させ, その時間の経過に伴う落下 仰転虫数率老求的，得られた時間致落下仰転率回帰直線 から，主として $\mathrm{KT}_{50}$ 值を概算する。また一方，滤紙専用 に改良した電気抵抗式水分計を用いて，それぞれ異なる 湿度環境に所定の洔間扔かれたあとの濾紙の moisture 在測定記録する。そしてこれらの結果と生物試験の結果 の関倸を求め，そ杞に基いて環境湿度の影響々 knock down 効果つ変動老考察する.

\section{実験結果および考察}

実駼結果は表 1 にま上めた。なお，knock down 効果 の変動状沉を図示した表中の線分は，時間致落下们転萃 回㷌直線の水平面への投影図であり，左端汶 $\mathrm{KT}_{5}$, 中央 は $\mathrm{KT}_{50}$ ，右端は $\mathrm{KT}_{95}$ を示す。したがつてその線分の 短いものほど回师直線の slope が急なことを示してい る. また，この実験に用いた電気抵抗式水分計の測定許 容範囲は 4 20\%であるので, 低湿度 (R.H. 27〜33\%) に扔かれた濾紙の場合は，寸なわち，4\%以下の微量の 
表1 湿度の異つた環境にそれぞれの時間和かれたDDVP 残渣面(滤紙)の moisture の変化とイェバニに対する knock down 效果の変動

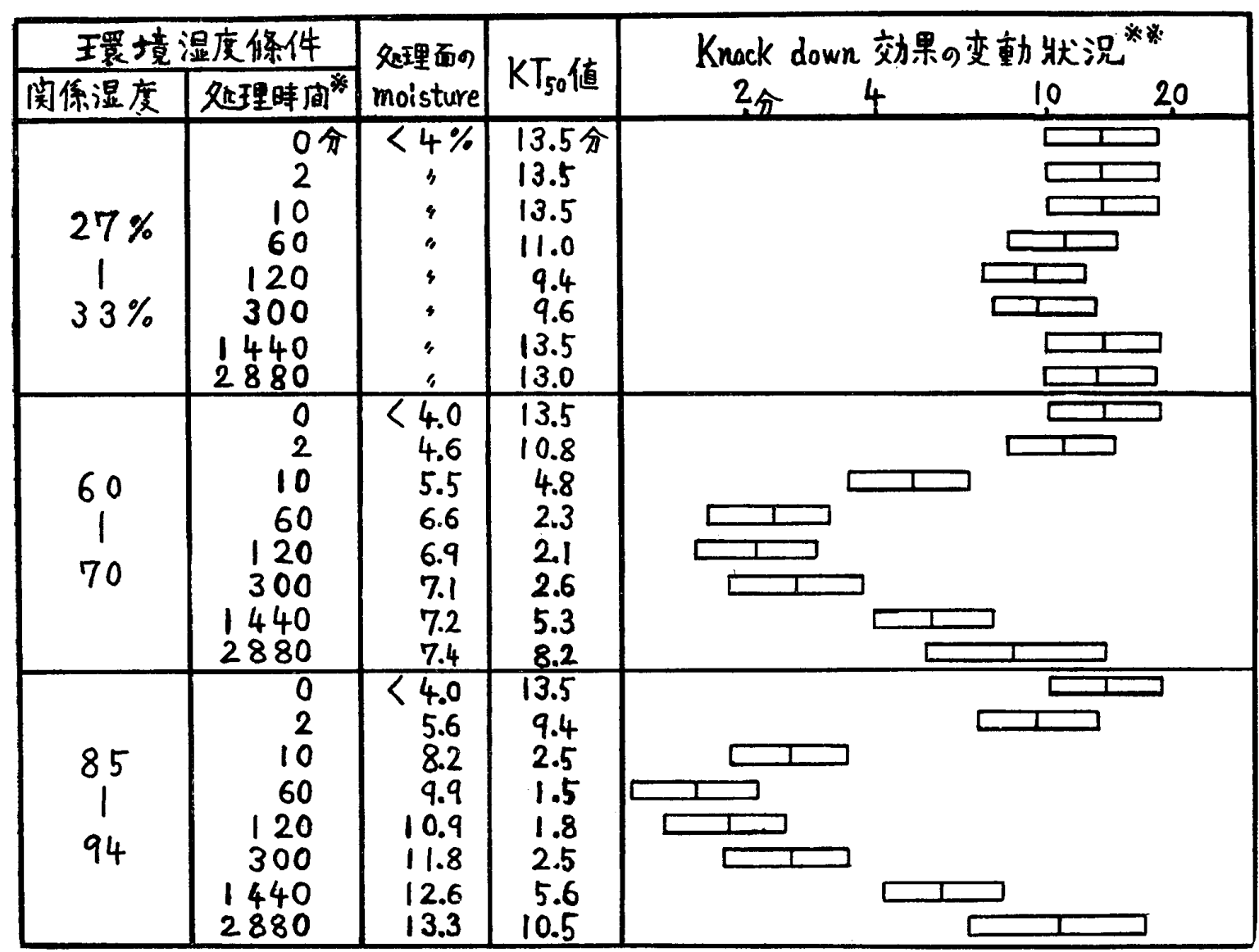

註＊䂝渣面をそれぞれの湿度環境にさらした時間を示す。 0 分とはその環境に移す直前の 結果であり，24〜25C，R.H.33〜 45\%の奏験室にそのまま扔かれていたものである.

**継続接触法门結果で, 左端は $\mathrm{KT}_{5}$, 中央が $\mathrm{KT}_{50}$, 右端は $\mathrm{KT}_{95}$ であり，それぞれ対 数値で示されている。

moisture の変化は具体的には表示できなかつた。

すでに前報で述べたように，殺虫剂処理面の微量の moisture の存在は, 処理面上の 有効残渣量の時間的な 変化，いわゆる，処理面における残渣の行動に関与する ものと推考されているので，環境湿度の影響を考察する に当つては, 関係湿度の程度そのものだけではなく，む しろ，その湿度条件におかれた時間の長短が重要な意味 をもつてくるものと思われる.

まずはじめに，電気抵抗式水分計を用いて，普通に室 内 (R.H. 33〜 45\%)におかれていた乾燥濾紙を，あらか じめ準備しておいた異なつたそれぞれの湿度環境に移し た場合の， moisture の時間的な変化を検討した。 その 結果によれば濾紙の moisture の変化は一般的には，そ れがおかれていた環境湿度の高低と当然に平衡関係を示 しているということができるが，濾紙の moisture の量 の時間的な変化は，多湿な条件におかれたものほど顕著 で，そのような環境に 2 分間程度の極めて短時間おかれ ただけでも moisture の量は敏感に増大し，表 1 に示す
ようにそここにおかれた時間の長さと対応した変動を示 すことが確認された。

さて，湿度の比較的低い環境(R.H. $27 \sim 33 \%$ ) に殺虫 剤を処理した濾紙面残渣をおいた場合の, 処理面の moisture の変化と $\mathrm{KT}_{50}$ 值の関係を考察すると, 表 1 から 明らかなように，処理面の moisture はその環境にさら された時間の長さとは殆んど関係なく，この場合は，総 て $4 \%$ 以下の安定した值を示していることがわかる. そ してそのように処理面の moisture が常に 4 \%以下で大 きな変動を示さない場合には，その環境にそれぞれの時 間おかれた残渣の $\mathrm{KT}_{50}$ 值の間にもまた大差がなく比較 的安定していて，KT $\mathrm{KT}_{50}$ 值の変動は殆んど 認められない 上いうことができる。すなわち，処理面が $30 \%$ 前後の 比較的低湿度環境におかれた場合には，この実験で示 した時間の範囲ではそこにおかれたそれぞれの残渣の $\mathrm{KT}_{50}$ 值の変動は極めて少いという事実が明らかとなつ たのである。

しかしながら，処理面のおかれた環境湿度が比較的高 
廨 生 動 物

い場合 (R.H. $60 \%$ 以上)には，すなわち，処理面の moisture が湿度変化によつて短時閒のうちに $4 \%$ を超えて 変化するようになると, その環境にさらされた時間の長 さに対応する，それぞれの残渣の $\mathrm{KT}_{50}$ 值もまた大きく 異なつてきて，それらの間の関係は急激な変動を示すよ らになる。この程度の処理面の微量の moisture の変化 は外見的には殆んどわからないものであるが，これが knock down 効果を大きく変動させる一つの要因となつ てくることは，特に注目されなければならない。

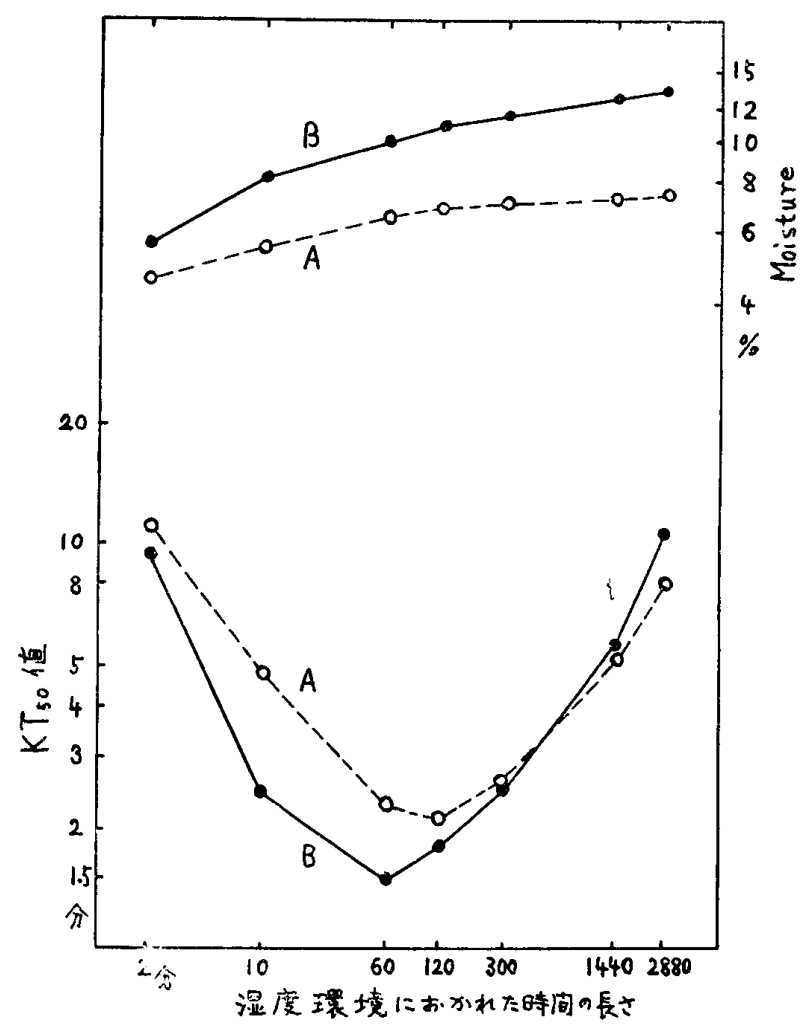

図 1 巽つた温度環境にそれぞれの時間扔かれた あとの DDVP 滤紙面残椬の示す moisture の変化と执かれた時閔に対応する $\mathrm{KT}_{50}$ 值 の変動

$$
\begin{aligned}
& \text { 註 A …R.H. } 60 \sim 70 \% \\
& \text { B …R.H. } 85 \sim 94 \% \\
& \text { な扔，縦軸，横軸とも対数值で示してある。 }
\end{aligned}
$$

このように処理面の moisture が時間の経過と共に 4 \%を超えて大きく変動する場合には， $\mathrm{KT}_{50}$ 值もまた それに伴つて変動するわけであるが，そこに見られる $\mathrm{KT}_{50}$ 值の閒の変動現象はまた複雑で, 図 1 に示すよ5 にその現象は単純な方向性を示さず，そこには特殊な一 つの定まつた傾向が認められるのである. 寸なわち, 残 渣がより多湿な環境におかれた場合，そのおかれた時間 の長さが異ると，その時間に対応するそれぞれの残渣の $\mathrm{KT}_{50}$ 值は顕著に異り, まずはじめは減少の方向へと変 動し,さらに長時間おかれた残渣の場合は，逆に増大の 傾向をたどるよらになる，そしてそこには，図 1 からも
明らかなように, turning point なるものが認められる のである.なお，第 I 報では，処理面の微量の moisture （この場合は相対湿潤指数で示された）の変化と $\mathrm{KT}_{50}$ 值の変動は逆の相関を示し, 直線的な関倸の認められる ことを報告したが，その場合の実験のように極めて短時 間の moisture の処理では，たしかに，そのような直線 関係が認められるのであるが，今回のように残渣がさら に長時間多湿な条件におかれると，いわゆる turning point が現れてくるのである.

かかる turning point の認められるに至る時間は，乙 の残渣のおかれた環境湿度の高低によつてまた異り，こ の実験で示した処理薬量では，高湿度 (R.H. 85〜94\%) におかれた場合には60 分後に認められ，中湿度 (R.H. 60〜70\%)の場合のそれは 120 分後であり，高湿度の場 合の方がより早期に現われる.

さらにまた，中，高両湿度環境における，それぞれの turning point で調べられた $\mathrm{KT}_{50}$ 值を比較してみると， 中湿度環境におかれた場合のそれは 2.1 分であるに対し 高湿度の場合のそれは 1.5 分上なつており，高湿度環境 におかれた場合のそれが最少の $\mathrm{KT}_{50}$ 值を示している.

一方それぞれの湿度環境に 2,880 分の長時間おかれたあ との $\mathrm{KT}_{50}$ 值の相対関係は前者の場合とは逆で, 中湿度 におかれた残渣つ $\mathrm{KT}_{50}$ 值が 8.2 分であるに対し，高湿 度のそれは 10.5 分とこの場合汇長くなつている（表 2 参 照)。このように湿度の異る環境に一定時間おかれたあ

\begin{tabular}{|c|c|c|c|}
\hline \multirow{2}{*}{ 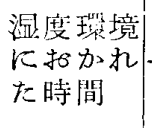 } & 関 & 係 湿 & 度 \\
\hline & $27 \sim 33 \%$ & $60 \sim 70 \%$ & $85 \sim 94 \%$ \\
\hline 0 分 & 13.5分 & 13.5分 & 13.5 分 \\
\hline 2 & 13.5 & 10.8 & 9.4 \\
\hline 10 & 13.5 & 4.8 & 2.5 \\
\hline 60 & 11.0 & 2.3 & 1.5 \\
\hline 120 & 9.4 & 2.1 & 1.8 \\
\hline 300 & 9.6 & 2.6 & 2.5 \\
\hline 1440 & 13.5 & 5.3 & 5.6 \\
\hline 2880 & 13.5 & 8.2 & 10.5 \\
\hline
\end{tabular}

表 2 異つた湿度環境に一定時間竹かれた あとの残椬の示す $\mathrm{KT}_{50}$ の比䡆

との残渣の示す $\mathrm{KT}_{50}$ 值の相対関係が，それぞれの湿度 環境におかれた時間の長さによつて，それが長くなると 逆の結果を示すようになつてくることは, moisture の 影響と残渣の行動を考察する上にまた注目されなけれ注 ならない。

すでに第 I報でもふれたが， moisture の存在は処理 面における残渣の行動を助長するものであるという仮定 
をおくならば，環境湿度の影響と knock down 効果の 変動する現象は, 以上の実験結果から次のよ5に説明す ることができる.

まず，殺虫㶡を残留処理した場合，その処理面が吸収 性であれば，撒布した薬剤のかなりの部分はその内層人 滲透し去り，一旦そこで吸着保持されるので，特にかかる 薬剂のその後の行動が問題となつてくるわけである. 処 理面がより多湿な環境にさらされると，処理面の moisture は急速に增大する結果, 何等かの機構で, 内層に 吸着保持されていた薬剂の行動が助長され，この吸着薬 剂はより急速に表層へと blooming してきて，処理面の 表層の，いわゆる有効残渣量が増大してくるものと考え られ， $\mathrm{KT}_{50}$ 值はそれを反映して，急速にまずはじめは 小となる方向へと変動する傾向を示したのであろう。し かし，内層の吸着量には限度があるから，表層への補給 量は時間の経過と共に次第に減少してくるはずであり， また表層に blooming した薬刜もさらに空間へと揮散消 失してしまうので，一旦増加を示した表層の有効残渣量 は再び減少してくるわけである，このように一旦増大し た表層の有效残渣量が再び減少し始める時期が，いわゆ る turning point であると推定される.そしてその後は 有效残渣量の減少を反映して $\mathrm{KT}_{50}$ 值はまた逆に増大の 方向へと変動を示したものと思われる.

また，環境湿度の違いによつて，turning point の発 現時期が異つたり，それぞれの湿度環境に一定時間おか れたあとの $\mathrm{KT}_{50}$ 值の相対関係が異つてくる現象は，残 渣の行動からさらに次のように説明することができよ う. 環境湿度が異るとそこにおかれた処理面の moisture の増加率が異つてくるわけであるから，それが内層 に吸着されている薬剤の行動,すなわち， blooming の速 度や量に関係してくるものと考えられ，残渣がより多湿 な条件におかれた場合ほど moisture は急速な增加を示 寸から，それに伴つて表層の有効残渣量も急激に増大し てくるため，比較的短時間のうちに有効残渣量は最大值 を示すようになり， $\mathrm{KT}_{50}$ 值もそれを反映した 結果を示 すのであろら。そして限られた量の吸着薬戍が，そのよ らに一時に多量に表層入出てきてしまう結果，一度増大 した有効残渣は，その後は空間人と揮散し去り減少の一 途をたどるのみとなるから，そこでこの場合は $\mathrm{KT}_{50}$ 值 も比較的早期に増大の傾向を示すようになつてしまうの であろうと推論される。

第 I 報に述べられているような，顕著に moisture の 影響をうける比較的蒸気圧の高い殺虫剤の，特に残渣の 効力試験においては，従来あまりかえりみられていなか つたが，このような環境湿度や moisture の影響を考虑 することが，試験結果の再現性を高める上に望ましく思
われる。

\section{総 括}

DDVP の濾紙面残渣を選び，イエバエ成虫を指示昆 虫として用い, knock down 効果を変動させる環境湿度 の影響を検討した.

処理面が比較的低、湿度環境(R.H. 27〜33\%)におか れた場合には，処理面の moisture は電気抵抗式水分計 で測定した結果によると，この実験で示した範囲では， その環境におかれた時間とは関係なく，つねに $4 \%$ 以下 の安定した值を示し，このように処理面の moisture が 安定していて変動のみられない場合には，それぞれの時 間そこにおか扎た残渣の $\mathrm{KT}_{50}$ 值の間にもまた大差がな く，その変動は比較的少いことが明らかとなつた。

処理面がより多湿な環境(R.H. 60 \%以上)におかれ， その moisture が 4 \%を超えて変化するようになると， その環境におかれた時間に対応する，それぞれの残渣の 示寸 $\mathrm{KT}_{50}$ 值の間には大きな差巽が認められるようにな る.かかる場合の $\mathrm{KT}_{50}$ 值の変動する現象はまた複雑な 傾向走し，そこには，いわゆる turning point なるも のが認められてくる．また，環境湿度の違いによつて， その turning point の発現時期が異ることや，それぞれ の湿度環境に一定時間おかれたあとの $\mathrm{KT}_{50}$ 值の相対関 係が，その環境におかれた時間の長さによつて異つてく ることなども実験的に明らかとなつた。

以上の結果に基き，また，すでに第川報でもふれたが moisture の存在は処理面における残渣の行動を助長す るものと仮定するならば， knock down 効果を変動させ る環境湿度の影響は次のように説明される。環境湿度の 変化は平衡的にまず処理面の微量の moisture を変化さ せ，その moisture の変化は処理面における残渣の行動 に関与し，処理面の表層のいわゆる有効残渣量を大きく 複雑に変動させる結果，それが knock down 効果の特 殊な変動となつて現われてくるものと推考した。

\section{参考交献}

1) 井上義郷 (1961)：衛生動物，12(3)：179-183. -

2）井上義楖 (1962)：衛生動物，13(1)：67-69. -3) 井上義郷 (1956)：衛生動物，7 (1)：43-50. -4) 鈴 木猛, 遠山輝萨 (1957)：防虫科学, 22 (3) : 283-292.

-5) 平社俊之助 (1958)：衛生動物，9(3)：191-197.

一6) 深谷昌次万編集 (1960)：昆虫実験法.28頁，日 本植物防度協会, 東京.

\section{Summary}

It has been already recognized by the present author (1961) that the knock down effect of insecticide is widely fluctuated under presence of minute 
moisture and such a phenomenon due to the moisture is the most evident in case of a volatile insecticide, for instance, DDVP or lindane when applied on an absorptive material such as filter paper.

In this paper, the relationship between the amount of moisture contained within filter paper to which the insecticide is applied and the environmental humidity was investigated under laboratory condition.

For measuring the amount of moisture an electric moisture meter was run. Using house flies the variability of knock down effect of DDVP impregnated papers previously exposed in three different humidities was investigated.

Through these experiments, it was confirmed that the relationship between the amount of moisture and relative humidity of the environments showed direct proportion.

When the treated surface was exposed under the condition of constant temperature of $25^{\circ} \pm 1^{\circ} \mathrm{C}$ and relative humidity of $27-33$ per cent the average moisture value of the filter paper surface was determined to be less than 4 per cent. The time length of exposure in this constant condition did not affect.

Under the presence of such minute moisture the knock down effect is invariable. However, in case of a high humidity condition the filter paper moisture increases rapidly; when exposed at a high relative humidity, ranging from 60 per cent to 94 per cent, the moisture of filter paper increases beyond 4 per cent up to 13.3 per cent in accordance with the time of exposure. This results, even a short period exposure to a environmental humidity, caused an instability of knock down effect.

It was supposed, that the minute moisture supports the blooming of the insecticide impregnated in the treated material.

\title{
Trap-hut による殺虫剂残留噴霧の蚊に 対する効果の観察1)
}

\section{The assessment of residual effect of insecticides to mosquito using a trap-hut}

\author{
鈴木猛2) 武出植人2,3) 栗原毅2) \\ Takeshi Suzuki, Ueto Takeda and Takeshi Kurihara
}

蚊あるいは八エに対する殺虫剤残渣の残効性について は，薬剤処理をほどこした基材（べニヤ板など）を恒温 ないし室温に保存し，各放置期間後に昆虫を一定時間こ れに接触せしめ，その死亡摔を求める方法がしばしばと られている.しかし，この試験方法は，狭い密閉空器 (シャーレなど)内で，昆虫を半ば強制的に残渣に接触せ しめる点に難点があり，異種薬剂の残効性を比較するた めには一灾の目的を達するとはいうものの，実地の残効

1) This investigation was supported by a PHS research grant E-3328 (R 1) from National Institute of Allergy and Infectious Diseases, NIH, Public Health Service.

2) 東京大学伝染病研究所寄生虫研究部（主任 传々 学教授)

Department of Parasitology, the Institute for Infectious Diseases, University of Tokyo (Chief : Prof. Manabu Sasa)

3）明治製菓製薬部 Meiji Seika Co. Ltd.
性を必らずしもそのまま示しているとはいえない，その ためには, 野外に扔いて, 自由に昆虫の侵入できる小屋 をつくり，その内壁に薬剤処理をほどこして，侵入した 昆虫の死亡率を求める方法が望をしい，

ここに報告する方法は, 蚊を対象とし, 内壁に殺虫剤 処理をほどこした小屋を用意し，逆もどりできない構造 の入口と出口をしつらえ，出口にはトラップをしかけて 野外に 1 晚放置し, 小屋内およびトラップ内の蚊の死亡 率を求めたものである。な拉小屋の中央には，蚊を誘引 する目的で，ドライアイスを置いた。

この方法には，まだ改良される心゙き余地があるが，一 つの試みとして，得られた結果を報告する.

この研究を進めるにあたつて，御指導いただいた佐々 学教授，および御援助いただいた松永秀子氏に梁謝す る.

\section{実験方法}

実験に使用した Trap-hut は, $150 \mathrm{~cm} \times 95 \mathrm{~cm} \times 95 \mathrm{~cm}$ 